\title{
Case Study for Selected Heavy Elements in Blood and Plasma from Six Female Patients with Systemic Sclerosis (Scleroderma, SSc). The Concen- trations of Mercury, Lead, Antimony, Cobalt, Copper, and Zinc
}

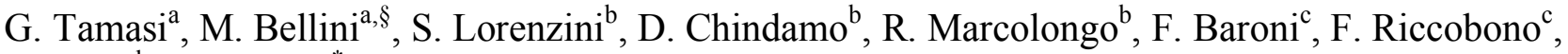 \\ R. Netti ${ }^{\mathrm{d}}$ and R. Cini ${ }^{*}, \mathrm{a}$
}

\author{
${ }^{a}$ Dipartimento di Scienze e Tecnologie Chimiche e dei Biosistemi, Università di Siena, Via Aldo Moro 2, I-53100 Siena, \\ Italia \\ ${ }^{b}$ Dipartimento di Medicina Clinica e Scienze Immunologiche, Sezione di Reumatologia, Policlinico Santa Maria \\ alle Scotte, Università di Siena, Via M. Bracci, I-53100 Siena, Italia
}

${ }^{c}$ Dipartimento di Scienze Ambientali Giacomino Sarfatti, Sezione di Geochimica Ambientale e Conservazione del
Patrimonio Lapideo Culturale, Università di Siena, Via Laterina, I-53100 Siena, Italia

${ }^{d}$ Agenzia di Protezione Ambientale della Toscana, Dipartimento della Provincia di Grosseto, Via Fiume 35, I-58100 Grosseto, Italia

${ }^{\S}$ Present Address: Siena Biotech SpA, Via Fiorentina 1, I-53100 Siena, Italia

\begin{abstract}
Samples of total blood (1T-6T) were collected from six patients (1-6) with Systemic Sclerosis (SSc) and analyzed for their content of mercury, lead, antimony, cobalt, copper, and zinc through AASGF (atomic absorption spectroscopy - graphite furnace), HR-ICP-MS (high resolution inductively-coupled plasma mass spectroscopy) and CVAAT (cold vapor atomic absorption technique). The blood samples (7CT, 8CT) from two "healthy subjects" $(\mathbf{7}, \mathbf{8})$ were also collected and analyzed. Furthermore, plasma samples (1P-6P, and 7CP and $\mathbf{8 C P}$ ) were prepared from fresh blood samples and analyzed for the same elements. The summary for $\mathrm{Hg}$, usually considered highly toxic, is as follows. Interestingly, three of six total blood samples had concentrations of mercury $(1 \mathrm{~T}, 11.0(4) \mu \mathrm{g} / \mathrm{L} ; 2 \mathrm{~T}, 8.2(3) ; 4 \mathrm{~T}, 7.4(3))$ significantly higher than the control from this work $(5.6(6) \mu \mathrm{g} / \mathrm{L})$ and the control from the literature $(5.3 \mu \mathrm{g} / \mathrm{L})$. The concentration of lead for the total blood samples is in the range 82.7(5) - 36.9(5) $\mu \mathrm{g} / \mathrm{L}$ and agrees well with average values for women from literature, $70 \mu \mathrm{g} / \mathrm{L}$. The average concentration for the essential element zinc for the samples $1 \mathrm{~T}-6 \mathrm{~T}$ is $6658 \mu \mathrm{g} / \mathrm{L}$, which compares well with the mean value from literature $(5561 \mu \mathrm{g} / \mathrm{L}$ for "healthy subjects").
\end{abstract}

\section{INTRODUCTION}

Significant toxic compound and heavy element intake by the body is considered a potential co-factor in triggering auto-immune diseases [1-3]. To our knowledge, there have been no large systematic investigations on the concentration of heavy elements in the body of patients with auto-immune diseases. Among other auto-immune diseases, systemic sclerosis or scleroderma ( $\mathrm{SSc}$ ) is a multi-system disorder characterized by Raynaud's phenomenon, proliferative vascular lesions and abundant deposition of collagen in the skin and internal organs (notably the heart, lungs, kidneys, and gastrointestinal tract) [4]; the etiology and pathogenesis of SSc are unknown. Although the characteristics of the disease are multi-factorial, immune system activation plays a central role in the development of its pathology; in fact, several cytokines, including IL-2, IL-6, TNF- $\alpha$, are known to be crucial in the development of tissue remodeling in SSc. Furthermore, mononuclear cells and T-cells predominate in the

*Address correspondence to this author at the Dipartimento di Scienze e Tecnologie Chimiche e dei Biosistemi, Università di Siena, Via Aldo Moro 2, I-53100 Siena, Italia; E-mail: cini@unisi.it dermal infiltrate in the inflammatory stages of SSc, and they show excessive functional activity in the peripheral blood of SSc patients [5-7].

Mercury, cadmium, lead, arsenic, antimony and tin are non-essential, toxic elements. They tend to accumulate in food chains and they have long biological half-lives in humans. However, it has yet to be mentioned that trace elements that are considered toxic can become of nutritional significance under certain circumstances of physiologic stress in animals and humans [8]. Furthermore, beneficial effects on human health of arsenic compounds have been reported; for example, in the case of treatments of certain diseases like leukemia [9]. Some authors have previously claimed that arsenic might have nutritional value in certain conditions [10]. Cobalt, copper, and other heavy metals are essential trace elements, but they too are toxic when their concentrations are relatively high. Possible mechanisms of action of these metals might include inhibition of enzymes, denaturation of protein, or increased susceptibility to infection due to immuno-suppression [11-14]. Metal exposure may occur also by contamination of food and drinking water. Several authors have suggested that the ingestion of one or more heavy elements may be important in the etiology of some rheumatic diseases like rheumatoid arthritis and SSc. 
The work by Casciola-Rosen et al. [15] suggested a model for the pathogenesis of SSc in which metals and free oxygen radicals play a central and synergic role. This conclusion came from experimental studies that showed that the autoantigens targeted in diffuse SSc are unified by their susceptibility to fragmentation in metal-dependent reactions that require the formation of reactive oxygen species. These studies show the importance of metal ions and of reactive oxygen radicals in damage processes during ischemia-reperfusion, and they present evidence for increased generation of these radicals in $\mathrm{SSc}$ patients.

Other studies have subsequently reported that the occasional intake of metals by the body, as well as prolonged intake from polluted environments, increases the rate of SSc in both males and females. For instance, Arnett et al. [16] showed that the mean urinary mercury levels were significantly elevated in anti-fibrillarin antibody-positive patients with SSc when compared to those in other patients without anti-fibrillarin antibodies and controls. These findings suggested that further epidemiological and basic science studies about the effects of mercury are necessary in patients with SSc, especially those expressing anti-fibrillarin antibodies. Overzet et al. [17] wished to determine whether SSc autoantigens, such as small nucleolar RNP SC-auto-antigens, associate with phosphorylated serine/arginine splicing factors during apoptosis (a similar effect had been shown for patients with systemic lupus erythematosus); thus, they screened a panel of monoclonal antibodies derived from mice exposed to mercury. They concluded that the immune response to fibrillarin that characterizes a subset of patients with SSc may be related to cell death induced by apoptotic stimuli (e.g., irradiation or chemical toxin, etc.) or by exposure to mercury.

Kuchma et al. [18], in a study aimed to determine the effect of a high level of industrial pollution on the development of Raynaud's syndrome and pulmonary arterial hypertension in patients with SSc and lupus erythematosus, showed that people living in highly polluted areas had a severe course of Raynaud's syndrome. Metal accumulation was decisive in patients with SSc in the development of Raynaud's syndrome, and the key role was assigned to lead and other heavy metals. The conclusions by the authors are that vascular disorders in patients with SSc living in heavily contaminated areas are aggravated due to direct damage from heavy metals. There are also other studies reporting data relevant to the effects played by metals on the immune system [19-23]. Very recently, many studies have been focused on the relationships between heavy metal exposures and autoimmune diseases (see for examples Refs 24-27). Research on the content of trace elements in non-articular rheumatism syndromes has been carried out in the recent years (see for an example Ref 28).

In connection with these premises, some of us have recently performed a series of analytical determinations of the levels of vanadium, cobalt, arsenic, lead, mercury, chromium and other elements in the drinking water of the Siena countryside, especially that from the Amiata mountain area, which is volcanically active and rich in metal- and Assulfide-containing mineral deposits [29]. A preliminary epidemiological and statistical study was also performed on certain autoimmune diseases, AIDs (SSc, lupus erythemato- sus and rheumatoid arthritis), and cancer diseases with patients from the entire district of Siena [30]. The data showed a peak for the year 1995 (4.8 patients with AID per 100,000 residents) and a smooth decrease in the rate of AIDs up to the year 2000 (2.3 patients with AIDs per 100,000 residents). A preliminary statistical study directed by one of the authors (RM) and conducted during the past ten years at the clinic of Rheumatology, University of Siena, on the rate of SC in patients from the volcanic Amiata mountain area population, showed significantly higher values when compared to a control population. ${ }^{1}$

It should be noted that the reference values for most of the trace elements in blood, urine, tissues and organs in humans and other animals is currently a matter of intensive research in several laboratories world-wide [31-32].

On the basis of these facts, we planned to determine the content of a series of heavy elements in the blood and plasma of patients affected by SSc. The patients were chosen from those treated at the Clinic of Rheumatology at the University of Siena. They included women aged 42-69; differences in their area of residence, nutrition and life habits were not significant.

As SSc is a rare auto-immune disease the number of patients that could be selected was small [4].

\section{EXPERIMENTAL SECTION}

Sample Collections: Informed consent was obtained for all patients and controls before the study. Fifteen milliliters of blood was drawn from the SSc patients at the clinic of Rheumatology, University of Siena. There were six patients (all females, mean age $54 \pm 14$ y) who fulfilled the preliminary criteria for SSc of the American College of Rheumatology [33] and two sex- and age-matched controls (females, mean age $49 \pm 4 \mathrm{y}$ ).

The disease duration was $6.0 \pm 2.6 \mathrm{y}$. All patients had skin involvement (limited in two patients and diffuse in the remaining), while the internal organs were affected in all patients. All patients were under treatment with Iloprost $(0.15$ $\mathrm{mg} / \mathrm{month})$.

All of the patients were from Italy; three lived in Siena, one in Florence, one in Perugia, and one on the island of Capri (Naples).

The working activities of the patients are as follows: two were housewives; one, a nurse; one, an office-worker; one, a trader; and one, a farmer.

Preparation of the Samples: Each $15 \mathrm{~mL}$ sample of total blood was divided into two parts: one $(7.5 \mathrm{~mL})$ was the total blood sample (xT) which was stored at $4{ }^{\circ} \mathrm{C}$, and the other $(7.5 \mathrm{~mL})$ was centrifuged at $800 \mathrm{~g}$ to separate the plasma fraction $(\mathrm{xP})$ from the heavy red-cell fraction; this was collected and stored at $4{ }^{\circ} \mathrm{C}$. All of the total blood samples and plasma samples were mineralized (see below).

Mineralization Procedure: Nitric acid (6 mL Suprapur ${ }^{\circledR}$ $\mathrm{HNO}_{3} 65 \%$, w/w; Merck, Darmstäd, Germany) and hydrogen peroxide (1 mL, Suprapur ${ }^{\circledR} \mathrm{H}_{2} \mathrm{O}_{2} 33 \%$, w/w, Merck) were added to each sample $(2.00 \mathrm{~g})$. All of the samples and the blank (6 mL, $\left.\mathrm{HNO}_{3} 65 \% ; 1 \mathrm{~mL}, \mathrm{H}_{2} \mathrm{O}_{2} 33 \%\right)$ were put in

\footnotetext{
${ }^{1}$ Marcolongo, R. unpublished data, 2007.
} 
poly-tetra-fluoro-ethylene (Teflon ${ }^{\circledR}$, PTFE) vessels, which in turn, were loaded into a microwave oven (Etos 900, Microwave Labstation; Milestone, MLS-1200 Mega) and heated under rotation (Rotore MRD-1000) for 25 minutes. The time/power program applied during the mineralization process is listed in Table 1. Then, the PTFE vessels were cooled down to $25^{\circ} \mathrm{C}$, the mixtures were centrifuged at $4000 \mathrm{rpm}$ and the supernatants were diluted to $100 \mathrm{~mL}$ with ultra-pure $\mathrm{H}_{2} \mathrm{O}$. The mineralized samples and the blank were analyzed via AAS, HR-ICP-MS, and CVAAT (see below).

Table 1. Time/Power Program for the Mineralization Procedure

\begin{tabular}{|c|c|c|}
\hline Step & Time (min) & Power (Watt) \\
\hline \hline 1 & 2 & 250 \\
\hline 2 & 2 & 0 \\
\hline 3 & 6 & 250 \\
\hline 4 & 5 & 400 \\
\hline 5 & 5 & 650 \\
\hline 6 & 0 & 0 \\
\hline
\end{tabular}

Atomic Absorption Spectroscopy (AAS): These analyses were performed by using a Perkin Elmer Aanalyst 100 machine equipped with an HGA-800 spectrometer and an AS-72 auto-sampler (Perkin-Elmer) with atomization atmosphere and a cooling stream of ultrapure argon. The graphite tubes used for the analyses were usually a pyrolitic-type without platform (Perkin-Elmer), except in a few cases when measurements were carried out with L'vov concave platform graphite furnace tubes (Perkin-Elmer). All lamps used were hollow cathode multi-element lamps, except for $\mathrm{Pb}$. The sample volume was $20 \mathrm{~mL}$ for all the samples. The thermal programs for all the elements are reported in Table 2 and consist of drying, pyrolysis and atomization steps. Standard solutions $\left(1 \mathrm{~g} / \mathrm{L}\right.$ of metal, each from Merck) of $\mathrm{M}\left(\mathrm{NO}_{3}\right)_{2}$, $(\mathrm{M}$; $\mathrm{Co}, \mathrm{Pb})$, ultrapure $\mathrm{Cu}$, in $0.5 \mathrm{~mol} / \mathrm{L}$ nitric acid were freshly diluted before the analyses. The data collection was performed via a WinLab Ver.3.2 package run on a Pentium machine.

Table 2. AAS Thermal Program. The Values Represent, in Order, Temperature $\left({ }^{\circ} \mathrm{C}\right)$, Ramp Time (s), and Plateau Time (s)

\begin{tabular}{|c|c|c|c|c|c|}
\hline & Drying & Pyrolysis & Cooling & Atomization & Cleaning \\
\hline \hline \multirow{2}{*}{$\mathrm{Co}$} & 120 & 500 & 20 & 2500 & 2600 \\
& $20 / 20$ & $10 / 15$ & $5 / 10$ & $0 / 5$ & $1 / 3$ \\
\hline \multirow{2}{*}{$\mathrm{Cu}$} & 120 & 500 & 20 & 2300 & 2600 \\
& $20 / 20$ & $10 / 20$ & $5 / 10$ & $0 / 5$ & $1 / 3$ \\
\hline $\mathrm{Pb}$ & 120 & 700 & 20 & 1800 & 2600 \\
& $10 / 15$ & $10 / 15$ & $10 / 10$ & $0 / 5$ & $5 / 3$ \\
\hline
\end{tabular}

High Resolution Inductively-Coupled Plasma-Mass Spectrometry (HR-ICP-MS): The analyses were performed on the samples by using a Perkin Elmer ELAN 6100 instrument and Elan Instrument Software Ver.3.3. Selected analytical conditions and parameters are reported in Table $\mathbf{3}$.

Three certified standard materials were used for comparative purposes: GBW-07603, vegetable materials (National Research Centre for Certified Reference Materials, Beijing, China); SRM-966, bovine blood (National Institute of Standards and Technology, NIST, Gaithersburg, MD; USA), and Seronorm ${ }^{\mathrm{TM}}$ Trace Element Human Serum Level 1 (REF 20140, LOT MI0181, SERO AS, P.O. Box 24 No1375 Billingstad, Norway). They were freshly prepared.

Table 3. ELAN 6100 Instrumental Conditions and Method Parameters for HR-ICP-MS

\begin{tabular}{|c|c|}
\hline Condition/Parameter & Value/Method \\
\hline \hline RF power (Watt) & 1050 \\
\hline Plasma argon flow (L/min) & 15 \\
\hline Nebulizer gas flow (L/min) & $0.9-1.0$ \\
\hline Sample uptake rate (mL/min) & 1.5 \\
\hline Sample introduction system & Cross-flow with spray chamber \\
\hline Detector mode & Dual mode \\
\hline Lens & Autolens \\
\hline Sample/skimmer cones & Nickel \\
\hline Scanning mode & Peak hopping \\
\hline Number of sweeps/readings & 10 \\
\hline Number of replicates & 4 \\
\hline
\end{tabular}

Analysis of Total Mercury through the Cold Vapor Atomic Absorption Technique, (CVAAT): The analyses were performed by using the CETAC M6000A in continuous flow, double ray, equipped with 2 quartz cells, a tin(II) chloride reactor, gas-liquid separation system, NAFION ${ }^{\circledR}$ drying device, and mercury vapor lamp. The mineralized samples (5 $\mathrm{mL}$ each) were previously mixed with $\mathrm{KMnO}_{4}(50 \mu \mathrm{L}, 5 \%)$. The selected instrumental details are reported in Table 4.

Table 4. Instrumental Conditions for CVAAT

\begin{tabular}{|c|c|}
\hline Condition/Parameter & Value/Method \\
\hline \hline Cell length (mm) & 220 \\
\hline Cell temperature $\left({ }^{\circ} \mathrm{C}\right)$ & 70 \\
\hline Gas flow $\left(\mathrm{N}_{2}, \mathrm{~mL} \mathrm{~min}^{-1}\right)$ & 100 \\
\hline Number of replicate measurements & 4 \\
\hline Base line beginning acquisition time $(\mathrm{s})$ & 12 \\
\hline Base line ending acquisition time $(\mathrm{s})$ & 253.7 \\
\hline Wavelength (nm) & $\mathrm{SnCl}_{2} \cdot 2 \mathrm{H}_{2} \mathrm{O}, 10 \%, \mathrm{HCl}, 7 \%$ \\
\hline Aqueous reducing solution $(\mathrm{w} / \mathrm{w})$ & \\
\hline
\end{tabular}


Table 5. Concentration of Selected Elements $(\mu \mathrm{g} / \mathrm{L})$ in the Blood Samples $(x T)$ and the Blood Plasma (xP) from Patients with SSc (1-6), Obtained via HR-ICP-MS. Reference Values (RV) for Blood Samples from Healthy Subjects are Reported in the Text for Comparative Purposes. Controls from this Work are 7 and 8 (See Text)

\begin{tabular}{|c|c|c|c|c|c|c|}
\hline & $\mathrm{Hg}^{\mathrm{a}}$ & $\mathbf{P b}$ & Sb & Co & $\mathrm{Cu}$ & $\mathbf{Z n}$ \\
\hline $\mathbf{1 T}$ & $11.0(4)$ & $72.6(5)$ & $1.06(3)$ & $0.58(3)$ & $896(3)$ & $3760(20)$ \\
\hline $1 \mathrm{P}$ & & $<75^{\mathrm{b}}$ & & $<25^{\mathrm{b}}$ & $1001(10)^{b}$ & \\
\hline $2 \mathrm{~T}$ & $8.2(3)$ & $45.1(5)$ & $2.38(4)$ & $1.04(4)$ & $846(3)$ & $6351(23)$ \\
\hline $2 \mathrm{P}$ & & $<75^{\mathrm{b}}$ & & $<25^{\mathrm{b}}$ & $1060(8)^{\mathrm{b}}$ & \\
\hline $3 \mathrm{~T}$ & $3.8(2)$ & $73.6(5)$ & $1.95(3)$ & $2.70(5)$ & $1057(4)$ & 4074(20) \\
\hline $3 \mathrm{P}$ & $1.85(8)$ & $67.9(5)$ & $1.77(4)$ & $1.01(3)$ & $1243(5)$ & $1818(12)$ \\
\hline $4 \mathrm{P}$ & $3.9(1)$ & $28.8(5)$ & $0.65(2)$ & $<0.05$ & $998(3)$ & 2723(18) \\
\hline $5 \mathrm{~T}$ & $1.64(7)$ & $36.9(5)$ & $0.52(2)$ & $<0.05$ & 794(3) & $6652(22)$ \\
\hline $5 \mathrm{P}$ & $1.61(7)$ & $4.8(3)$ & nd & $<0.05$ & $872(4)$ & 1751(18) \\
\hline $6 \mathrm{~T}$ & $1.58(7)$ & $82.7(5)$ & $1.80(3)$ & $0.20(2)$ & $961(4)$ & $8714(25)$ \\
\hline $6 \mathrm{P}$ & $1.27(7)$ & $4.5(3)$ & $0.80(2)$ & nd & $926(4)$ & 2926(20) \\
\hline $7 \mathrm{~T}$ & $2.5(1)$ & $26.6(4)$ & $0.79(2)$ & $<0.05$ & $1043(4)$ & $7577(25)$ \\
\hline $7 \mathrm{P}$ & $0.88(5)$ & $7.6(3)$ & $0.48(1)$ & $<0.05$ & $1056(4)$ & $1777(12)$ \\
\hline
\end{tabular}

${ }^{a}$ The values for Hg were obtained through CVAAT.

${ }^{\mathrm{b}}$ Values from AAS. As regrds $\mathrm{Pb}$ and Co the detection limits for AAS were 75 and $25 \mu \mathrm{g} / \mathrm{L}$, respectively, because fifty times dilutions after mineralization. nd, not determined.

\section{RESULTS AND DISCUSSION}

The concentration of the elements analyzed for all the samples are reported in Table 5 (the patients are marked 16). The concentration for element $\mathrm{X}$ in the blood and plasma are $\mathrm{C}_{\mathrm{X}}^{\mathrm{T}}$ and $\mathrm{C}_{\mathrm{X}}^{\mathrm{P}}$, respectively. The selected values considered as references for blood and plasma for "healthy subjects" found in the literature are reported as $\mathrm{RV}^{\mathrm{T}} \mathrm{x}$ and $\mathrm{RV}^{\mathrm{P}} \mathrm{x}$. Control samples from this laboratory were obtained from the blood of two "healthy women", who had never been diagnosed with SSc or any other auto-immune disease. The patients and controls were in the age range of 42-63 year.

Mercury: The $\mathrm{C}_{\mathrm{Hg}}^{\mathrm{T}}$ values for the $1 \mathrm{~T}, 2 \mathrm{~T}$ and $4 \mathrm{~T}$ samples (11.0(4), 8.2(3), 7.4(3) $\mu \mathrm{g} / \mathrm{L}$, average 8.9(19)) are higher than the value obtained by Minoia et al. $(5.3 \mu \mathrm{g} / \mathrm{L})$ [34] and much higher than the value obtained by Schober et al. (average $1.19 \mu \mathrm{g} / \mathrm{L}$ ) [35]. The latter, more recent, study was performed through the CVAAT technique on total blood samples from 759 women aged 30-49 y. The reference value determined for adults with a fish consumption of 2-3 meals per month is $2.0 \mu \mathrm{g} / \mathrm{L}$ from 2310 samples collected from the general population [36]. It is noteworthy that the values obtained in the present work for the NIST standard blood, which were declared to be $31.4 \pm 1.7 \mu \mathrm{g} / \mathrm{L}$, are $28.7(6) \mu \mathrm{g} / \mathrm{L}$. Therefore, the values determined in this laboratory for SSc patients and for healthy subjects are reliable. The $\mathrm{C}_{\mathrm{Hg}}^{\mathrm{T}}$ values for $3 \mathrm{~T}, 5 \mathrm{~T}$ and $6 \mathrm{~T}(3.8(2), 1.64(7)$ and $1.58(7) \mu \mathrm{g} / \mathrm{L})$ as well as those for the two controls (7T and $8 \mathrm{~T}, 2.5(1) \mu \mathrm{g} / \mathrm{L}$ ) compare well with those from the extensive work by Schober [35]. It should be noted that the $\mathrm{C}_{\mathrm{Hg}}^{\mathrm{T}}$ is higher than $\mathrm{C}_{\mathrm{Hg}}^{\mathrm{P}}$ (3.5(2), 4.2(2), 1.85(8), 3.9(1), 1.61(7), 1.27(7) $\mu \mathrm{g} / \mathrm{L}, 1 \mathrm{P}-6 \mathrm{P})$ for all samples (average 2.7(13)). The corresponding values for the controls are $0.88(5)$ and $0.15(4) \mu \mathrm{g} / \mathrm{L}$ (7P and 8P). It should be noted that the concentrations of mercury from the Seronorm ${ }^{\mathrm{TM}}$ standard as declared and as found from this work are $0.96 \pm 0.10$ and $0.85 \pm 0.07 \mu \mathrm{g} / \mathrm{L}$, respectively.

On the basis of these data, it seems that the majority of patients with SSc (four out of six) have a content of $\mathrm{Hg}$ in their blood that is higher than that of both the two relevant study controls and the average values taken from previous studies by others. This fact does not prove a correlation between the content of $\mathrm{Hg}$ in blood and SSc disease; however, it at least suggests that a wider analytical and epidemiological investigation should be performed, by selecting a larger number of patients from both sexes. In regards to patients $\mathbf{1}$, 
2 and $4\left(C^{T}{ }_{H g}\right.$ values higher than the mean values $5.5(5) \mu \mathrm{g} / \mathrm{L}$ out of six), it should be noted that all of them had more than ten dental amalgams for many years. Patient $\mathbf{1}$ was a cigarette smoker (ca 7/d) for two decades. A specific high ingestion of mercury from polluted water and meals had apparently not played a role for this patient, based on her nutritional habits. She lives in an area that is not significantly polluted by emissions from industrial settlements, car traffic, agriculture activities, etc. She worked as a nurse for two decades in a main regional clinic.

One of the referees suggested that the contents of trace elements in the blood might vary with age. In fact, it should be noted that patients $\mathbf{1}$ and $\mathbf{4}$ are 65 and 69 years old, respectively, whereas the mean age of patients $\mathbf{3}, \mathbf{5}$ and $\mathbf{6}$ is $51.4 \pm 2.5 \mathrm{y}$. These data confirm the hypothesis of the reviewer, even though patient 2 (42 years old) does not fit this pattern. The patients' diets in the period of time before the sample collections are not known.

Lead: The concentration of lead for the blood samples, $\mathrm{C}_{\mathrm{Pb}}^{\mathrm{T}}$ (72.6(5), 45.1(5), 73.6(5), 42.2(5), 36.9(5), 82.7(5) $\mu \mathrm{g} / \mathrm{L}, 1 \mathrm{~T}-6 \mathrm{~T}$, average 58.9(16)), agrees well with recent mean values for women $(70 \mu \mathrm{g} / \mathrm{L})$ obtained from Wilhelm M. et al. [36]. The lead concentration in blood samples from a Detroit (Michigan) female population (885 adults) was found to be as low as $27 \mu \mathrm{g} / \mathrm{L}$ (average) by Nriagu et al. [37]. The $\mathrm{C}_{\mathrm{Pb}}^{\mathrm{T}}$ values for the two controls are 26.6(4) and 96.1(6) $\mu \mathrm{g} / \mathrm{L}$ (7T and $8 \mathrm{~T}$, respectively). It should be noted that the $\mathrm{C}_{\mathrm{Pb}}^{\mathrm{T}}$ values are higher than the corresponding $\mathrm{C}_{\mathrm{Pb}}^{\mathrm{P}}$ values (42.9(4), 40.6(4), 67.9(5), 28.8(5), 4.8(3), 4.5(3) $\mu \mathrm{g} / \mathrm{L}$, 1P-6P, average $31.6(244) \mu \mathrm{g} / \mathrm{L})$. The two controls have $\mathrm{C}_{\mathrm{Pb}}^{\mathrm{P}}$ values of 7.6(3) and 82.6(6) $\mu \mathrm{g} / \mathrm{L}$. In conclusion, the concentration of lead is not significantly higher than the reference values in six out of eight of the samples analyzed in this study. SSc pathologies seem not to be correlated with an anomalous concentration of $\mathrm{Pb}$ in blood and plasma. The value determined in this work for the NIST blood sample differs by less than $8 \%$ from that declared $(253 \pm 2.2 \mu \mathrm{g} / \mathrm{L})$. The concentration for lead in the Seronorm ${ }^{\mathrm{TM}}$ human serum standard is $2.20(5) \mu \mathrm{g} / \mathrm{L}$, in good agreement with the declared one $(2.9(1) \mu \mathrm{g} / \mathrm{L})$.

Antimony: The concentration of antimony for the total blood samples, $\mathrm{C}_{\mathrm{Sb}}^{\mathrm{T}}(1.06(3), 2.38(4), 1.95(3), 0.94(2)$, $0.52(2), 1.80(3) \mu \mathrm{g} / \mathrm{L}, \mathbf{1 T}-6 \mathrm{~T}$, average $1.44(71))$, is close or lower than the mean value found in previous work by others: $3.19 \mu \mathrm{g} / \mathrm{L}$ [38]. The $\mathrm{C}^{\mathrm{P}}{ }_{\mathrm{Sb}}$ values $(1.77(3), 1.77(3), 0.65(2)$ $\mu \mathrm{g} / \mathrm{L}, 2 \mathrm{P}-4 \mathrm{P}, 0.80(2) \mu \mathrm{g} / \mathrm{L}$ for $6 \mathrm{~T}, 1.30(54)$ average) are close to the values found for total blood samples. The values for the two controls are $0.79(2)$ and $0.51(2)(\mathrm{T})$, and $0.48(1)$ and $0.65(3) \mu \mathrm{g} / \mathrm{L}(\mathrm{P})$, respectively. The value found for the NIST bovine blood standard is $3.28(4) \mu \mathrm{g} / \mathrm{L}$, whereas for the Seronorm $^{\mathrm{TM}}$ human serum standard, the concentration of $\mathrm{Sb}$ is $10.6(6.3) \mu \mathrm{g} / \mathrm{L}$ (declared) and 9.4(2) (found). These data show that antimony is not present in higher concentrations in the blood of the six SSc patients when compared to "healthy" people. A recent analytical study suggested that antimony might be a sensitive indicator (together with lead and manganese) of diseases connected with blood pressure and/or the renal system (preeclampsia among women without occupational exposure) (Vigeh et al., 2006, and references cited therein).
Cobalt: The cobalt concentrations in blood samples for three patients out of six $(0.58(3), 1.04(4), 2.70(5)$ 1T-3T) are a little higher than the average value $(0.39 \mu \mathrm{g} / \mathrm{L})$ found by Minoia et al. [34], and are also in agreement with the mean value found by Vigeh et al. $(0.54 \mu \mathrm{g} / \mathrm{L})$ [38]. The other three patients had very small $\mathrm{C}^{\mathrm{T}}{ }_{\mathrm{Co}}$ values $(<0.05 \mu \mathrm{g} / \mathrm{L}, 4 \mathrm{~T}$ and $5 \mathrm{~T}$ and $0.20(2), 6 \mathrm{~T})$. The $\mathrm{C}_{\mathrm{P}}^{\mathrm{P}}$ values for plasma $(0.92(3)$, $1.01(3),<0.05,<0.05 \mu \mathrm{g} / \mathrm{L}, 2 \mathrm{P}-5 \mathrm{P})$ are not much different from the corresponding $\mathrm{C}^{\mathrm{T}}{ }_{\mathrm{Co}}$ values. The concentration of cobalt found in the two controls from this work is lower than $0.05 \mu \mathrm{g} / \mathrm{L}$ for both blood and plasma. The concentration of cobalt found in the vegetal standard is $0.41(2) \mu \mathrm{g} / \mathrm{L}$ (declared $0.41 \pm 0.03)$, whereas the values found for the Seronorm ${ }^{\mathrm{TM}}$ human serum standard are 1.12(2) $\mu \mathrm{g} / \mathrm{L}$ (declared) and $0.96(4) \mu \mathrm{g} / \mathrm{L}$, respectively.

Copper: The $\mathrm{C}_{\mathrm{Cu}}^{\mathrm{T}}$ values for blood $(896(3), 846(3)$, 1057(4), 826(3), 794(3), 961(4) $\mu \mathrm{g} / \mathrm{L}$, 1T-6T, average $897(98))$ are a little lower than the values reported by Minoia et al. $(1200 \mu \mathrm{g} / \mathrm{L})$ [34] and the values reported by others: $1068-1461 \mu \mathrm{g} / \mathrm{L}$ [39] and $1075 \mu \mathrm{g} / \mathrm{L}$ for eight healthy Mexican women [40]. The $\mathrm{C}^{\mathrm{P}}{ }_{\mathrm{Cu}}$ are values are 1128(4), 1051(4), 1243(4), 998(3), 872(4), 926(4) $\mu \mathrm{g} / \mathrm{L}$ for patients 1P-6P, with an average of $1036(135) \mu \mathrm{g} / \mathrm{L}$. It should be noted that the $\mathrm{C}_{\mathrm{Cu}}^{\mathrm{T}}$ values are lower than the corresponding $\mathrm{C}_{\mathrm{Cu}}^{\mathrm{P}}$ values in five out of six patients. The values for the two controls from this work are 1043(4) and 887(3) $\mu \mathrm{g} / \mathrm{L}$ (average 965(110)) for blood and 1056(4) and 1099(4) $\mu \mathrm{g} / \mathrm{L}$ (average 1078(30)) for plasma. The value for the NIST total blood bovine standard is $1203(4) \mu \mathrm{g} / \mathrm{L}$. The values for the Seronorm $^{\mathrm{TM}}$ human serum standard are $1180 \pm 90 \mu \mathrm{g} / \mathrm{L}$ (declared) and $1153(4) \mu \mathrm{g} / \mathrm{L}$ (found). It appears that the content of copper in blood from SSc patients is not a specific anomaly when compared to the standard controls from this work. It therefore seems that the SSc patients have a lower content of copper than healthy patients; interestingly, this could be related to the role played by copper in inflammation and in oxygen radical concentrations.

Zinc: The concentration of zinc in the total blood samples $\left(\mathrm{C}^{\mathrm{T}}{ }_{\mathrm{Zn}}\right)$ averages 6658(2583) $\mu \mathrm{g} / \mathrm{L}(3760(20), 6351(23)$, 4074(20), 10394(30), 6652(22), 8714(25) $\mu \mathrm{g} / \mathrm{L}, 1 \mathrm{~T}-6 \mathrm{~T})$ as compared to $\mathrm{RV}^{\mathrm{T}}{ }_{\mathrm{Zn}}(6340 \mu \mathrm{g} / \mathrm{L})$ [34] and to the mean value from other authors $(5561(1057) \mu \mathrm{g} / \mathrm{L}$ [38]). The values for the two controls from this work are $7577(25)$ and $8037(25)$ $\mu \mathrm{g} / \mathrm{L}$. The average $\mathrm{C}^{\mathrm{P}}{ }_{\mathrm{Zn}}$ value of $2104(584) \mu \mathrm{g} / \mathrm{L}$ (1457(12), 1951(12), 1818(12), 2723(18), 1751(18), 2926(20) $\mu \mathrm{g} / \mathrm{L}, 1 \mathrm{P}-$ 6P) is higher than the $\mathrm{RV}^{\mathrm{P}} \mathrm{Zn}(922 \mu \mathrm{g} / \mathrm{L})$ [34]. The values for the controls from this work are 1777(12) and 3456(20) $\mu \mathrm{g} / \mathrm{L}$. The values found for the Seronorm ${ }^{\mathrm{TM}}$ human serum standard are $1330 \pm 100$ (declared) and 1354(6) $\mu \mathrm{g} / \mathrm{L}$, respectively. The average value for $\mathrm{C}^{\mathrm{T}} \mathrm{zn}$ agrees with the value from previous work, but the individual values span a large interval. Patient 1 has a small $\mathrm{C}^{\mathrm{T}}{ }_{\mathrm{Zn}}$ value and patient $\mathbf{4}$ has a high $\mathrm{C}^{\mathrm{T}}{ }_{\mathrm{Zn}}$ value when compared to the mean values from this work and those from other works. It seems that the metabolism of this essential element might be significantly altered for subjects with SSc.

\section{CONCLUSIONS}

This work shows a substantial agreement for the concentrations of the selected elements when analyzed through the three different techniques. The reliability of the methods was 
assured by the results obtained for blood standards from the NIST and a GBW vegetal standard. Notwithstanding, HRICP-MS technique with the procedure used in this work overestimated the content of mercury in blood and, at a lesser extent in plasma, whereas CVAAT was much more reliable. For this reason the values for mercury reported in the present work are those obtained via CVAAT. It has to be noted that a methodology for determination of mercury, cadmium and lead in blood using HR-ICP-MS has been developed, validated and is now in press [41].

Even though the small number of SSc patients examined (it has to be noted that SSc affects 200-300 persons per million, and overall population of Siena is below 60,000) does not allow any concrete correlation between the concentration of an element and the diagnosis of SSc disease, it can be noted that: (1) high concentrations of mercury were found in three out of six patients; (2) high concentrations of cadmium were found in two SSc patients; (3) the concentrations of copper are smaller in SSc patients than in "healthy subjects" from other works and a little smaller than those from the two controls used here; and (4) the concentrations of zinc in these SSc patients range from 3760-10394 $\mu \mathrm{g} / \mathrm{L}$, showing a larger variability than for copper and zinc found in non-SSc people. Therefore, it is highly advisable that a more thorough analytical work be performed by increasing the number of SSc patients, the number of samples collected from each patient as function of time from diagnosis, and the number of samples from the "healthy subjects," with the aim of defining a reliable reference value for each element. Other elements should also be included in the panel, and specific sampling strategies should be designed and performed. For example, patients might be selected from restricted areas or based on genetic characteristics, nutritional styles, sex, other diseases diagnosed before SSc, etc. Work is planned in this clinic and these chemical laboratories with the purpose of increasing the number of samples and patients whose disease was diagnosed shortly before sample collection, and to study the influence of anti-SSc therapy on the metabolism of heavy elements. Finally, analysis of the trend for the $\mathrm{Hg}$ content in the blood of patients with SSc as it relates to age confirms that this heavy metal accumulates even under scleroderma conditions. On the contrary, no such relationship could be confirmed for the other trace elements.

\section{ACKNOWLEDGEMENTS}

The authors acknowledge the University of Siena for funding through PAR (Piano di Ateneo per la Ricerca). RC and GT thank Ministero dell'Università e della Ricerca Scientifica e Tecnologica (MURST, Rome) through PRIN (Progetto di Rilevante Interesse Nazionale) year 2004 (contract $\mathrm{n}^{\circ} 2004032118$ ).

A special thank goes to those who gave the blood samples.

\section{REFERENCES}

[1] Mayes, M.D. Environ. Health Perspect., 1999, 107, 743.

[2] Silver, R.M. Scleroderma and pseudoscleroderma: environmental exposure. In Systemic sclerosis. Clements, P.J.; Furst, D.E. (eds). Williams \& Wilkins, A Waverly Company, 1996, p. 81.

[3] Sternberg, E.M. Pathogenesis: environmental. In Systemic sclerosis. Clements, P.J.; Furst, D.E. (eds). Williams \& Wilkins, A Waverly Company, 1996, p. 203.
[4] Barnett, A.J. History of scleroderma. In Systemic sclerosis. Clements, P.J.; Furst, D.E. (eds). Williams \& Wilkins, A Waverly Company, 1996, p. 3.

[5] Varga, J.; Jimenez, S.A. Pathogenesis of scleroderma: cellular aspects. In Systemic sclerosis. Clements, P.J.; Furst, D.E. (eds). Williams \& Wilkins, A Waverly Company, 1996, p. 123.

[6] Williams, R.C. Jr. Autoimmun. Rev., 2007, 6, 204.

[7] Aliprantis, A.O.; Wang, J.; Fathman, J.W.; Lemaire, R.; Dorfman, D.M.; Lafyatis, R.; Glimcher, L.H. Proc. Natl. Acad. Sci., 2007, 104, 2827.

[8] Nielsen, F.H. Biol. Trace Elem. Res., 1990, 26-27, 599.

[9] Sordet, O.; Liao, Z.Y.; Liu, H.; Antony, S.; Stevens, E.V.; Kohlhagen, G.; Fu, H.; Pommier, Y. J. Biol. Chem., 2004, 279, 33968, and references cited therein.

[10] Frost, D.V. Sci. Total Environ., 1983, 28, 455.

[11] Bertin, G.; Averbeck, D. Biochimie, 2006, 88, 1549.

[12] Hengstler, J.G.; Bolm-Audorff, U.; Faldum, A.; Janssen, K.; Reifenrath, M.; Götte, W.; Jung, D.; Mayer-Popken, O.; Fuchs, J.; Gebhard, S.; Bienfait, H.G.; Schlink, K.; Dietrich, C.; Faust, D.; Epe, B.; Oesch, F. Carcinogenesis, 2003, 24, 63.

[13] Hong, K.-H.; Yoo, S.-A.; Kang, S.-S.; Choi, J.-J.; Kim, W.-U.; Cho, C.-S. Clin. Exp. Immun., 2006, 146, 362.

[14] Fraústo da Silva, J.J.R.; Williams, R.J.P. (eds). The Biological Chemistry of the Elements. The Inorganic Chemistry of Life. Second Edition. Oxford University Press. Oxford, UK, 2001.

[15] Casciola-Rosen, L.; Wigley, F.; Rosen, A. J. Exp. Med., 1997, 185, 71.

[16] Arnett, F.C.; Fritzler, M.J.; Ahn, C.; Holian, A. J. Rheumatol., 2000, 27, 405 .

[17] Overzet, K.; Gensler, T.J.; Kim, S.J.; Geiger, M.E.; van Venrooij, W.J.; Pollard, K.M.; Anderson, P.; Utz, P.J. Arthritis Rheum., 2000, 43, 1327.

[18] Kuchma, G.B.; Bagirova, V.V.; Setko, N.P. Ter. Arkh., 2001, 73, 37. [Article in Russian]. Abstract from NCBI (National Center for Biotechnology Information, National Library of Medicine, National Institute of Health), PubMed: http:/www.ncbi.nlm.nih.gov/entrez/ query.fgi?CMD=search \&DB=pubmed.

[19] Pollard, K.M.; Pearson, D.L.; Hultman, P.; Hildebrandt, B.; Kono, D.H. Environ. Health Perspect., 1999, 107, 729.

[20] Pollard, K.M.; Pearson, D.L.; Hultman, P.; Deane, T.N.; Lindh, U.; Kono, D.H. Environ. Health Perspect., 2001, 109, 27.

[21] Häggqvist, B.; Hultman, P. Clin. Exp. Immunol., 2005, 141, 422.

[22] Bigazzi, P.E. Environ. Health Perspect., 1999, 107(Suppl 5), 753.

[23] Tracey, A.S. J. Inorg. Biochem., 2000, 80, 11.

[24] Stejskal, V.; Hudecek, R.; Stejskal, J.; Sterzl, I. Neuro. Endocrinol. Lett., 2006, 27(Suppl 1), 7.

[25] Valentine-Thon, E.; Muller, K.E.; Guzzi, G.; Kreisel, S.; Ohnsorge, P.; Sandkamp, M. Neuro. Endocrinol. Lett., 2006, 27(Suppl 1), 17.

[26] Mishra, K.P.; Chauhan, U.K.; Naik, S. Hum. Exp. Toxicol., 2006, 25,661 .

[27] Vinay, D.S.; Kim, J.D.; Kwon, B.S. J. Immunol., 2006, 177, 5708.

[28] Rosborg, I.; Hyllén, E.; Lidbeck, J.; Nihlgård, B.; Gerhardsson, L. Sci. Total Environ., 2007, 385, 20.

[29] Tamasi, G.; Cini, R. Sci. Total Environ., 2004, 327, 41.

[30] Tamasi, G. The content of selected heavy metals and arsenic in waters from the Province of Siena. Can the assumption of certain elements be a cause for the insurgence of rheumatic auto-immune diseases?. Tesi di Laurea in Chimica (University of Siena, Printed in Italian), 2001.

[31] Gil, F.; Capitán-Vallvey, L.F.; De Santiago, E.; Ballista, J.; Pla, A.; Hernández, A.F.; Gutiérrez-Bedmar, M.; Fernández-Crehuet, J.; Gómez, J.; López-Guarnido, O.; Rodrigo, L.; Villanueva, E. Sci. Total Environ., 2006, 372, 49.

[32] Wilhelm, M.; Schulz, C.; Schwenk, M. Int. J. Hyg. Environ. Health, 2006, 209, 301.

[33] American Rheumatism Association. Subcommittee for scleroderma criteria of the American Rheumatism Association. Diagnostic and therapeutic criteria committee: preliminary criteria for the classification of systemic sclerosis (scleroderma). Arthritis Rheum., 1980, 23,581 .

[34] Minoia, C.; Sabbioni, E.; Apostoli, P.; Pietra, R.; Bozzoli, L.; Gallorini, M.; Nicolaou, G.; Alessio, L.; Capodoglio, E. Sci. Total Environ., 1990, 95, 89.

[35] Schober, S.E.; Sinks, T.H.; Jones, R.L.; Bolger, P.M.; McDowell, M.; Osterloh, J.; Garrett, E.S.; Canady, R.A.; Dillon, C.F.; Sun, Y.; 
Joseph, C.B.; Mahaffey, K.R. J. Am. Med. Assoc. JAMA, 2003, 289, 1667.

[36] Wilhelm, M.; Ewers, U.; Schulz, C. Int. J. Hyg. Environ. Health, 2004, 207, 69 .

[37] Nriagu, J.; Burt, B.; Linder, A.; Ismail, A.; Sohn, W. Int. J. Hyg. Environ. Health, 2006, 209, 109.

[38] Vigeh, M.; Yokoyama, K.; Ramezanzadeh, F.; Dahaghin, M.; Sakai, T.; Morita, Y.; Kitamura, F.; Sato, H.; Kobayashi, Y. Environ. Res., 2006, 100, 268.
[39] Alebic-Juretic, A.; Frkovic, A. J. Trace Elem. Med. Biol., 2005, 19 191, and references cited therein.

[40] De la Cruz, D.; Cruz, A.; Arteaga, M.; Castillo, L.; Tovalin, H. Contraception, 2005, 72, 122.

[41] McShane, W.J.; Pappas, R.S.; Wilson-McElprang, V.; Paschal, D. Spectrochim. Acta Part B: Atomic spectroscopy, Accepted manuscript, doi: 10.1016/j.sab.2008.03.016

Received: March 14, 2008

Revised: April 16, 2008

Accepted: April 30, 2008

(C) Tamasi et al.; Licensee Bentham Open.

This is an open access article distributed under the terms of the Creative Commons Attribution License (http://creativecommons.org/licenses/by/2.5/), which permits unrestrictive use, distribution, and reproduction in any medium, provided the original work is properly cited. 